\title{
LX. Account of two experiments on accidental colours; with observations on their theory
}

\author{
Sir David Brewster LL.D. F.R.S. V.P.R.S. Ed.
}

To cite this article: Sir David Brewster LL.D. F.R.S. V.P.R.S. Ed. (1834) LX. Account of two experiments on accidental colours; with observations on their theory, Philosophical Magazine Series 3, 4:23, 353-354, DOI: 10.1080/14786443408648353

To link to this article: http://dx.doi.org/10.1080/14786443408648353

册 Published online: 01 Jun 2009.

Submit your article to this journal $[\pi$

Џ Article views: 2

Q View related articles 두 


\section{[ 353 ]}

LX. Accont of two Experiments on Accidental Colbur's; woith Observations on their Theory. By Sir Davin Brewster, LL.D., F.R.S. \& V.P.R.S. Ed.

A LTHOUGH considerable progress bas been made in observing the phænomena of accidental colours in all the various forms under which they present themselves, yet we know almost nothing of the manner in which light acts upon the retina when it is rendered insensible to particular colours of the spectrum. In making some experiments on this subject, I observed two very curious facts, which possess some interest independent of their theoretical relations.

1. It has been long known that when the eye is under the influence of a luminous impression which causes it to see the accidental or complementary colour of the exciting light, the accidental colour often vanishes and re-appears. If a smart blow is given to the head when the eye sees the accidental colour in its first and brightest phase, it will instantly disappear, so that the vibration thus suddenly communicated to the retina restores to that membrane the sensibility to the primitive or exciting colour which it had lost. I varied this experiment by giving the blow to the head before the accidental colour was seen, that is, when the eye was still fixed upon the exciting colour. When this was done, and the eye quickly turned upon the white ground, the accidental colour was not visible:

I was now anxious to learn whether the same effect would be produced by strong vibrations communicated to the head through the intermedium of the air, and with this view I had a large gong powerfully struck close to my head when the accidental colour was a maximum. I could not observe, however, the slightest change either in the intensity or duration of the complementary impression.

2. The influence of strong light in rendering the retina partially insensible to red rays, even when these rays fall upon a part of the membrane which has not been directly acted upon by the strong light, has been finely shown by the experiment of Dr. Smith of Fochabers*, and I have mentioned in a former paper $\uparrow$ that a stick of red sealing-wax may be thus made to appear of a dark liver-brown colour.

If we apply the strong light to the eye when the sensibility of the retina has been locally diminished by looking at a red object, a total insensibility to red light will be produced. In order to observe this curious result in perfection, let the eye be steadily fixed for some time upon a seal of red wax

* Dr. Smith's paper will be found in Lond. and Edinb. Phil. Mag., vol. i. p. 250. $\dagger$ Ibid, p. 172 .

Third Series. Vol. 4. No. 23. May 1834. 
which reflects white light from all its elevated parts. When the eye has been so fatigued that it would see a bright accidental green, bring a candle close to the excited eye, and so near its axis that the red seal will be seen by rays which pass near the flame of the candle. When this is done, the red wax seal will be converted apparently into a seal of black wax, the lights reflected from its elevations being still distinctly seen. This experiment, when successfully made, affords one of the most remarkable optical deceptions with which I am acquainted.

The method now described of eliminating the impression of the primitive or exciting colour leads us to a very important determination in the theory of accidental colours. I endeavoured long ago to show from analogy, as well as from the evidence of experiment, that the vision of the primitive and the accidental colour is contemporaneous, in the same manner as the fundamental and the harmonic sound are heart contemporaneously by the ear. That this is the case may be shown in the following manner. When the eye is fatigued with the excitation of the red seal, a faint green phosphorescent-looking light covers for a while the surface of the red seal, occasionally overpassing its margin, showing, in the clearest manner, that the accidental green is seen at the same time with the exciting red. The effect of this vision of the green is to make the red appear much paler by its admixture with it. The red and green tend to produce whiteness; but as the direct red greatly predominates over the accidental green, the result is always a pale red. But when a brilliant fight is brought near the excited eye so as to extinguish completely the red rays, the phosphorescent green appears alone; and thus we have ocular demonstration that the accidental green is not the light of a white ground deprived of the red rays to which the eye has been rendered insensible, but is $a$ colorific impression generated in the retina itself, and superadded to the whiteness of the ground in the case when the eye is turned from the exciting colour to a white object. These results are obviously incompatible with the theory of accidental colours recently published by M. Plateau.

LXI. Observations on the Visibility of the Retina; with Remarks upon its probable Cause. By T. W. W.*

THE remarkable experiment in which the blood-vessels of 1 the retina are rendered visible has excited so much attention, that the following observations upon it may, perhaps,

* Communicated by the Author. For other papers on this subject see Lond. and Edinb. Phil. Mag. for January, February, and April. 